\title{
Comparative Study of Metal Contents in Brazilian Coffees Cultivated by Conventional and Organic Agriculture Applying Principal Component Analysis
}

\author{
José S. dos Santos, ${ }^{*, a}$ Maria Lúcia P. dos Santos ${ }^{a}$ and Melina M. Conti ${ }^{a}$ \\ ${ }^{a}$ Departamento de Ciências Naturais, Universidade Estadual do Sudoeste da Bahia, CP 95, \\ 45083-900 Vitória da Conquista-BA, Brazil
}

\begin{abstract}
Neste trabalho, avaliou-se a disponibilidade de nutrientes minerais e elementos tóxicos em cafés produzidos pelas agriculturas orgânica, tradicional e tecnológica no sudoeste da Bahia, Brasil. Os nutrientes minerais foram determinados em amostras de solos e tecidos de café por espectrometria de absorção atômica com chama (FAAS) e os elementos tóxicos $(\mathrm{Cr}, \mathrm{Ni}, \mathrm{Cd}$ e $\mathrm{Pb}$ ) por espectrometria de emissão ótica por plasma indutivamente acoplado (ICP OES). A aplicação de métodos estatísticos (análises de agrupamento e de componentes principais) aos resultados analíticos confirmou a importância do "período de conversão", durante o processo de mudança do manejo da cafeicultura tradicional para orgânica. Os resultados possibilitam inferir que o Cd, $\mathrm{Cu}, \mathrm{Zn}$ e outros elementos tóxicos contidos nos fertilizantes inorgânicos (utilizados na cafeicultura tradicional e tecnológica), e os níveis relativamente elevados de $\mathrm{Cu}$ e $\mathrm{Zn}$ presentes nos adubos orgânicos (utilizados na cafeicultura orgânica) podem causar aumentos dos níveis desses elementos nos solos agrícolas, podendo assim, passar para a cadeia alimentar através dos cultivos.
\end{abstract}

The aim of this study was to evaluate of availability of nutrients and toxic elements in green coffees produced in traditional, technological and transitional organic farms in Southwest BahiaBrazil. Levels of the nutrients minerals were determined directly in samples of soils and coffee tissues from four farms by flame atomic absorption spectrometry (FAAS) and toxic elements $(\mathrm{Cr}, \mathrm{Ni}, \mathrm{Cd}$ and $\mathrm{Pb})$ by inductively coupled plasma optical emission spectrometry (ICP OES). The application of statistical methods (cluster and principal components analysis) revealed the importance of the conversion period to guarantee a product genuinely organic during the change to organic agriculture. On the other hand, the study of correlations between agricultural methods and metals concentrations in coffee suggested that $\mathrm{Cd}, \mathrm{Cu}, \mathrm{Zn}$ and other toxic elements contained in some inorganic fertilizers used in the traditional and technological coffee farms may cause an increase of toxic metals concentration in the crop soil, be taken up by plants, and passed on in the food chain.

Keywords: organic coffee, available metals in soil, nutrients and toxic elements, technological coffee, traditional coffee, principal component analysis (PCA), organic farm

\section{Introduction}

Soil-to-plant transfer of heavy metals is the major pathway of human exposure to soil contamination. Health risk due to soil contamination with single toxic metal has been widely studied. However, in the reality, multiple contaminants often co-exist in the environment and health risk estimated on the basis of single contaminant may not be sufficient to predict the risk for mixed contaminants. Thus, the determination of toxic elements concentrations in foodstuff can provide important information on the impact of the use of chemical products in crops and on levels of environmental pollution in farms. Furthermore, such survey

*e-mail: zesoares25@ @otmail.com may indicate an appropriate agronomic management for foodstuffs cultivation. ${ }^{1,2}$

In its natural, shaded habitat, coffee is a sustainable crop. In the mid 20th century, however, with the advent of the green revolution an agrobusiness oriented scheme, that presed high technology on traditional farmer, varieties of high yielding coffee were pursued. ${ }^{3,4}$ Thus, food productivity had increased significantly due to new technologies, mechanization, use of chemicals and governmental policies. However, together with the positive effects on farming, some impacts like degradation of soil and water resources also occurred. ${ }^{5-7}$ For instance, the excessive application of fertilizers (quantity and frequency) usually exceeds the soil ability to retain and transform the nutrients and make them available according to the crop 
needs. ${ }^{8-12}$ Although fertilizers provide nutrients to crops, they can contain elements, such as toxic metals, that are potentially harmful for the environment. ${ }^{13-15}$

Nowadays there are three different agricultural methods applied for coffee cultivation in Southwest Bahia, Brazil: organic, traditional and technological procedures. The demand for organic products has created new export opportunities for the developing world. Typically, organic exports are sold at impressive premiums, often at prices 20 percent higher than those of identical items produced in non-organic farms. ${ }^{3,16}$

Because it is virtually impossible to distinguish a product produced by organic farming from one produced by conventional farming, organic farms must be certified by appropriate regulatory bodies. The certification allows the producers to sell their production under the designation "organic." This provides the consumer with a guarantee that the product purchased is genuinely the result of organic farming. The certification body validates the farm on the basis of standards, which determine the technical requirements, e.g., which products may be used for fertilization and processing, and what are the conversion periods. ${ }^{8,15}$

The time between the start of organic management and cultivation of crops is known as the conversion period. In Brazil, the minimum conversion period for plant products, produced annually, is 12 months prior to the start of the production cycle. For perennial plants (including coffee cultivation) the conversion period is 24 months from the date of starting organic management. Depending upon the past use of the land and ecological situations, the certification agency can extend or reduce the minimum conversion period. ${ }^{17}$

The aim of this work is to evaluate of availability of nutrients and toxic elements in green coffees produced in traditional, technological and transitional organic farms in Southwest Bahia-Brazil. The comparison of soils samples collected in each areas that applied different agricultural methods (organic, traditional and technological), was made based on contents of nutrients and toxic elements for the establishment of an environmental profile of coffee cultivation in Southwest Bahia-Brazil.

\section{Experimental}

\section{Definition of the problem}

The present work is a complement of the studies to evaluate the presence of nutrients and toxic elements in coffees cultivated during the process of conversion in two organic farm located in the southwest of the state of Bahia, Brazil, close to Vitória da Conquista City. ${ }^{17}$ It was demonstrated that coffees cultivated during the first year of the conversion process to organic agriculture presented relatively high levels of $\mathrm{Cd}, \mathrm{Zn}$ and $\mathrm{Cu}$. The values for cadmium content for the coffee samples exceeded the normal range for Brazilian coffees produced by traditional methods. On the other hand, the minimum conversion period for coffee cultivation is 24 months from the date of starting organic management.

Compared to a previous study, two different coffee farms (traditional and technological methods) were included in present work. The traditional coffee farm located among the geographical coordinates (latitude $15^{\circ} 0.0^{\prime} 36.1^{\prime \prime} \mathrm{S}$, longitude $40^{\circ} 47^{\prime} 35.6^{\prime \prime} \mathrm{W}$ and $866 \mathrm{~m}$ height) and the technological coffee farm among the geographical coordinates (latitude $15^{\circ} 30^{\prime} 18^{\prime \prime} \mathrm{S}$, longitude $41^{\circ} 14^{\prime} 21^{\prime \prime} \mathrm{W}$ and $627 \mathrm{~m}$ height). A reference soil from the forest reservations sites located around of the four coffee cultivation farms in study were also included (latitude $14^{\circ} 53^{\prime}$ 09. 2" S, longitude $40^{\circ} 47^{\prime} 59.7$ ' $\mathrm{W}$ and $871 \mathrm{~m}$ height). Two different coffee farms (traditional and technological methods) were included in present work. Furthermore, microwave-assisted sample preparation and determinations using ICP OES were also included here.

\section{Soil and plant sampling}

The soils and coffee plant tissues (leaves and fruits) were collected from each of the four coffee cultivation operations in April 2006 (flowering period) and August 2006 and 2007 (harvesting period) according to previous work. ${ }^{17}$

\section{Reagents}

All solutions were prepared using high purity deionized water obtained from a Millipure water purification system (Millipore, Bedford, MA, USA).

For extraction procedures, the following analytical grade reagents were used: nitric acid $\left(\mathrm{HNO}_{3} 65 \% \mathrm{v} / \mathrm{v}\right.$, Merck, Rio de Janeiro, RJ, Brazil), hydrochloric acid ( $\mathrm{HCl}$ $37 \% \mathrm{v} / \mathrm{v}$, Merck), perchloric acid $\left(\mathrm{HClO}_{4} 70 \% \mathrm{v} / \mathrm{v}\right.$, Merck) and hydrogen peroxide $\left(\mathrm{H}_{2} \mathrm{O}_{2}, 30 \% \mathrm{v} / \mathrm{v}\right.$, Merck).

Appropriate buffer solutions were used for calibrating the potentiometer at $\mathrm{pH}$ 4.0, 7.0 and 9.2.

For calibration of FAAS and ICP OES, analytical reference solutions in $1.0 \% \mathrm{v} / \mathrm{v} \mathrm{HNO}_{3}$ were prepared by successive dilution of $1000 \mathrm{mg} \mathrm{L}^{-1} \mathrm{Ca}, \mathrm{Mg}, \mathrm{Fe}, \mathrm{Mn}, \mathrm{Zn}$, $\mathrm{Cu}, \mathrm{Cr}, \mathrm{Cd}, \mathrm{Pb}$ and Ni Titrisol standard solutions (Merck, Darmstadt, Germany). All solutions were stored in decontaminated polypropylene bottles (Nalge Company, Rochester, NY, USA). 


\section{Apparatus}

For measurements, an air-acetylene flame atomic absorption spectrometer Perkin Elmer Analyst 200 (Norwalk, CT, USA) equipped with a deuterium background corrector and an inductively coupled argon optical emission spectrometer (ICP OES) radial Modula, Spectro, equipped with a radio frequency generator of $27.12 \mathrm{MHz}$ and effective wavelength running from 165 to $800 \mathrm{~nm}$ were used. Operational conditions for FAAS and ICP OES are shown in Table 1.

For extraction procedures of toxic elements a QWave-3000 microwave digestion system (Questron Corporation, Mississauga, ON, Canada) was used. The microwave oven is equipped with $100 \mathrm{~mL}$ PTFE vessels, a fluoropolymer coated oven cavity, cavity exhaust fan, removable 10-position sample carousel, and a hose to permit venting of fumes into a fume hood. A pressure sensor and an extension fiber optic probe were connected to one control vessel. To ensure similar amounts of microwave energy for all samples, the sample carousel was rotated $180^{\circ}$ forwards and backwards by an internal motor.

A potentiometer (Digimed DM 20, São Paulo, SP, Brazil) was employed for $\mathrm{pH}$ measurements in soils samples.

Table 1. Operational condition for ICP OES and FAAS

\begin{tabular}{lccc}
\hline \multicolumn{2}{c}{ ICP OES } & \multicolumn{2}{c}{ FAAS } \\
Applied power & $1.2 \mathrm{~kW}$ & Flame & Air/acetylene \\
$\begin{array}{l}\text { Observation } \\
\text { height }\end{array}$ & $12 \mathrm{~mm}$ & Fuel flow & $4.0 \mathrm{~L} \mathrm{~min}^{-1}$ \\
Sample flow & $1.5 \mathrm{~mL} \mathrm{~min}^{-1}$ & Oxidant flow & $12 \mathrm{~L} \mathrm{~min}^{-1}$ \\
Auxiliary gas & $1.2 \mathrm{~L} \mathrm{~min}^{-1}$ & & \\
\hline Element & Wavelength / & Wavelength / & Spectral \\
& nm & nm & resolution / nm \\
\hline $\mathrm{K}$ & & 766.5 & 0.7 \\
$\mathrm{Na}$ & & 589.0 & 0.2 \\
$\mathrm{Ca}$ & & 422.7 & 0.7 \\
$\mathrm{Mg}$ & & 285.2 & 0.7 \\
$\mathrm{Cu}$ & & 324.8 & 0.7 \\
$\mathrm{Fe}$ & 248.3 & 0.2 \\
$\mathrm{Mn}$ & & 279.5 & 0.2 \\
$\mathrm{Zn}$ & & 213.9 & 0.7 \\
$\mathrm{Cr}$ & & & \\
$\mathrm{Ni}$ & 284.3 & & \\
$\mathrm{Cd}$ & 221.6 & & \\
$\mathrm{~Pb}$ & 283.3 & & \\
\hline
\end{tabular}

\section{Preparation of plant tissue samples}

All glassware and polyethylene flasks used were cleaned with detergent solutions, soaked in $10 \% \mathrm{v} / \mathrm{v}$ nitric acid for $24 \mathrm{~h}$, rinsed with Millipure water, and dried in polypropylene containers. Extractions were made in triplicate for each sample.

Leaf and fruit (green coffee) samples were washed and dried as discussed in a previous work. ${ }^{17}$ Prior to chemical analysis, the dry leaf samples were ground into fine powder in a stainless steel mill and the green coffee samples were roasted at $300{ }^{\circ} \mathrm{C}$ in a laboratory roaster in $150 \mathrm{~g}$ batches.

For analysis of nutrients minerals contents $(\mathrm{K}, \mathrm{Na}, \mathrm{Ca}$, $\mathrm{Mg}, \mathrm{Cu}, \mathrm{Fe}, \mathrm{Mn}$ and $\mathrm{Zn}$ ), extractions were performed as previously discussed. ${ }^{17}$

Toxic elements ( $\mathrm{Cd}, \mathrm{Pb}, \mathrm{Ni}$ and $\mathrm{Cr}$ ) were extracted using microwave-assisted processes. A $100 \mathrm{mg}$ portion of the (leaf and fruits) dried and ground material was transferred into the polytetrafluoroethylene (PTFE) vessel. A volume of $2 \mathrm{~mL}$ of $65 \% \mathrm{v} / \mathrm{v} \mathrm{HNO}_{3}, 1 \mathrm{~mL}$ of $30 \% \mathrm{~m} / \mathrm{m} \mathrm{H}_{2} \mathrm{O}_{2}$ and $6 \mathrm{~mL}$ of Millipure water were added and the vessels were sealed. During this study the following microwave heating program was used: step $1,90^{\circ} \mathrm{C}$, ramp time $15 \mathrm{~min}$ and plateau time $10 \mathrm{~min}$; step $2,150{ }^{\circ} \mathrm{C}$, ramp time $10 \mathrm{~min}$ and plateau time $10 \mathrm{~min}$. An infrared sensor measured the temperature at the bottom of the reaction vessels. When decomposition is complete, the sample is transferred to a volumetric flask, the reaction vessels washed out with distilled water and the volume made up to $25 \mathrm{~mL}$. For each digestion, reagent blanks were prepared. Blanks were prepared using this same procedure.

\section{Preparation of soil samples}

After removal of visible pieces of plant residues, soils were dried at $60{ }^{\circ} \mathrm{C}$, homogenized, gently crushed and sieved to particle size lower than $2 \mathrm{~mm}$. A portion of each sample was ground to particle sizes lower than $63 \mu \mathrm{m}$ for metal extraction, as recommended by the EPA. ${ }^{23}$

For available metals, soils were extracted by Mehlich1 procedure $(5 \mathrm{~g}$ samples of soil were digested using $0.05 \mathrm{~mol} \mathrm{~L}^{-1} \mathrm{HCl}$ and $\left.1 \mathrm{~mol} \mathrm{~L}^{-1} \mathrm{H}_{2} \mathrm{SO}_{4}\right) \cdot{ }^{17,24-26}$

For total metals, soil was digested by the USEPA SW 846-3050 procedure: $0.5 \mathrm{~g}$ sample of soil was digested with concentrated nitric acid, concentrated hydrochloric acid and hydrogen peroxide, using open vessel digestion. ${ }^{17}$

\section{Analytical determinations}

Potassium, $\mathrm{Na}, \mathrm{Ca}, \mathrm{Mg}, \mathrm{Cu}, \mathrm{Fe}, \mathrm{Mn}$ and $\mathrm{Zn}$ were determined directly in the extract solution by FAAS and $\mathrm{Cr}, \mathrm{Ni}, \mathrm{Cd}$ and $\mathrm{Pb}$ by ICP OES. Instruments responses were periodically checked with known standards. Calibration curves were prepared by dilutions of stock solutions. All 
measurements were made in triplicate and the mean values were used for statistical data evaluation.

Organic matter $(\mathrm{OM})$ content in soil samples was estimated from the organic carbon content, obtained by oxidation with potassium dichromate in sulfuric acid according to method (Black, 1965) ${ }^{27}$ and $\mathrm{pH}$ was measured at a 1:2.5 soil/liquid ratio with $1 \mathrm{~mol} \mathrm{~L}^{-1} \mathrm{KCl}$ according to (ISO 1994). ${ }^{28}$

\section{Statistical data evaluation}

Due to the existence of different factors (agricultural methods, soil characteristics, weather and pollution) that could affect the content of the minerals or trace elements in coffee, the correlation (Pearson $r$ ) and principal component analysis (PCA) were applied to the concentration data in order to study the chemistry variables capable of promoting a characterization of the coffee produced in each area, and for establishment of an environmental profile of coffee cultivation in Southwest Bahia, Brazil.

A data matrix $(46 \times 10)$ was constructed whose rows corresponded to the different samples analyzed (cases) and whose columns corresponded to the content of the minerals or trace elements determined (variables). Data were processed by HCA (hierarchical cluster analysis) and PCA (principal component analysis).

In HCA, the squared Euclidian distance and coefficient of similarity were used to group the cases into clusters in terms of their nearness or similarity. The clustering method used was Ward's method.

Correlation analysis (Pearson r) was performed between the variables of fertilizers (organic residues, SSP and NPK) and organic, organic shaded, traditional and technological coffee. In order to test whether there was a significant difference in physicochemical parameters and metal contents between results obtained in crop soils (organic, organic shaded, traditional and technological managements) and natural soils (forest reservation), paired two-tailored t-tests were performed. All mathematical and statistical computations were made using Excel 2003 and SPSS 12.0 (SPSS, Chicago, IL, USA, 2001). ${ }^{24,25}$

\section{Results and Discussion} Analytical performance for the extraction/analysis
procedures

The analytical performance for the extraction/analysis procedures of $\mathrm{Cu}, \mathrm{Mn}$ and $\mathrm{Zn}$ by FAAS and $\mathrm{Cr}, \mathrm{Ni}, \mathrm{Cd}$ and $\mathrm{Pb}$ by ICP OES in plant tissue and soil samples is summarized in Table 2. The calibration graphs obtained for all elements were linear with correlation coefficients of at least 0.9985 for FAAS and 0.9991 for ICP OES.

Limits of detection (LOD) and limits of quantitation (LOQ) were calculated as three times and ten times, respectively, the standard deviation of the blank signal ( $n=12$ ) divided by the slope of each calibration graph. The analytical methods that involve extraction and analysis procedures, the LOD may be divided into two components, instrumental detection limit (IDL) and method detection limit (MDL). Similarly, the LOQ may be divided in instrumental quantification limit (IQL) and method quantification limit (MQL). For estimating MDL and MQL values, aqueous solutions containing each one of the chemical extractants used during the preparation step (plant tissue, soil samples and organic residues used as fertilizer) were used as blanks and the dilution factor of each procedure was considered. ${ }^{26,27}$

\section{Characteristics of the studied soils}

The physico-chemical parameters and metal contents in crop soils (organic, organic shaded, traditional and

Table 2. Limits of detection (LOD), limist of quantitation (LOQ), method detection limit (MDL) and method quantification limit (MQL) in $\mu g \mathrm{~g}^{-1}$

\begin{tabular}{|c|c|c|c|c|c|c|c|c|}
\hline & & $\mathrm{Cd}$ & $\mathrm{Pb}$ & $\mathrm{Cr}$ & $\mathrm{Ni}$ & $\mathrm{Cu}$ & $\mathrm{Zn}$ & $\mathrm{Mn}$ \\
\hline \multirow[t]{2}{*}{ Instrumental } & LOD & 0.25 & 0.50 & 4.00 & 3.00 & 0.1 & 0.1 & 0.15 \\
\hline & LOQ & 0.83 & 1.67 & 13.33 & 10.00 & 0.33 & 0.33 & 0.50 \\
\hline \multirow[t]{2}{*}{ Organic residues } & MDL & 0.005 & 0.01 & 0.08 & 0.06 & 0.002 & 0.002 & 0.003 \\
\hline & MQL & 0.017 & 0.033 & 0.27 & 0.20 & 0.007 & 0.007 & 0.010 \\
\hline \multirow[t]{2}{*}{ Soil (Mehlich1) } & MDL & 0.036 & 0.07 & 0.58 & 0.44 & 0.02 & 0.02 & 0.03 \\
\hline & MQL & 0.12 & 0.24 & 1.93 & 1.45 & 0.04 & 0.04 & 0.07 \\
\hline \multirow[t]{2}{*}{ Soil (EPA-3050) } & MDL & 0.006 & 0.011 & 0.09 & 0.06 & 0.002 & 0.002 & 0.004 \\
\hline & MQL & 0.018 & 0.036 & 0.28 & 0.22 & 0.006 & 0.006 & 0.011 \\
\hline \multirow[t]{2}{*}{ Plant tissue } & MDL & 0.005 & 0.01 & 0.08 & 0.06 & 0.002 & 0.002 & 0.003 \\
\hline & MQL & 0.017 & 0.033 & 0.27 & 0.20 & 0.007 & 0.007 & 0.010 \\
\hline
\end{tabular}


technological managements) and natural soils (forest reservation) are shown in Table 3. The results show that the mean concentrations of $\mathrm{Cr}$ decreased in the order: soils of technological and traditional farms $>$ soils of farms organic $>$ natural soils, while the mean $\mathrm{Pb}$ concentrations showed the order: soils of farm technological $>$ soils of farm traditional $>$ natural soils $>$ soils of farms organic. For all sites, there was a significant difference between the total $\mathrm{Cd}$ contents of crop and natural soils. According to a previous study, the total Cd content of all crop soils (organic, organic shaded, traditional and technological managements) ranged between $3.20-3.98 \mathrm{~m} \mathrm{~kg}^{-1}$ whereas the mean concentration of $\mathrm{Cd}$ in natural soils was of $0.27 \mathrm{mg} \mathrm{kg}^{-1} .{ }^{17}$

\section{Influence of inorganic fertilizer and organic residue used as fertilizer}

Coffee cultivation requires the use of fertilizers as sources of macronutrients like $\mathrm{N}, \mathrm{P}$ and $\mathrm{K}$, and also of micronutrients such as $\mathrm{S}, \mathrm{Fe}, \mathrm{Mn}, \mathrm{Cu}, \mathrm{B}$ and $\mathrm{Zn}$. In technological and traditional cultivation procedures, farmers use very large amounts of phosphate fertilizer. Almost all phosphate fertilizers contain not only major elements necessary for plant nutrition and growth but also trace metal impurities. These metals can accumulate in the soil, be taken up by plants, and passed on in the food chain to animals and humans.

In Brazil, the main manure used in organic coffee farm is residue from the coffee processing. Coffee processing generates residues in the form of pulp or husk. These represent approximately $78 \%$ of the berry. This organic residue, the outer hull, is further reincorporated to the tillage soil as fertilizer since it is rich in mineral and organic compounds. A chemical characterization of commercial fertilizers and organic manure commonly used for the coffee cultivation was carried out.
Table 4 shows the concentrations and standard deviations for the heavy metals in organic residue samples collected in five coffee processing plants located around of the two organic farms and three group of commercial fertilizers commonly used in the traditional and technological coffee farms: a NPK fertilizer 4-14-18 (containing 4\% N, $14 \% \mathrm{PO}_{4}$ as $\mathrm{P}_{2} \mathrm{O}_{5}$ and $18 \% \mathrm{~K}_{\text {as }} \mathrm{K}_{2} \mathrm{O}$ ) and two single superphosphate fertilizers-SSP (a SSP granulated with particle sizes of $2 \mathrm{~mm}$ and a SSP triturated with particle sizes lower than $50 \mu \mathrm{m}$ ). All organic residues samples contained appreciable concentrations of $\mathrm{Ni}, \mathrm{Cu}$ and $\mathrm{Zn}$, that may cause an increase of these elements with the application of the organic residues from coffee processing as fertilizer in the crop soils. The increase in the concentrations of $\mathrm{Ni}$ and $\mathrm{Cu}$ in the two organic crop soils compared to the natural soils (Table 3) can be an indicative of use of organic residues from the coffee processing in the cultivation.

The three group of commercial fertilizers used in the traditional and technological coffee farms are characterized by presenting high concentrations for toxic metals $(\mathrm{Cd}, \mathrm{Pb}$, $\mathrm{Cr}$ and $\mathrm{Ni}$ ) and mineral nutrients $(\mathrm{Cu}, \mathrm{Zn}$ and $\mathrm{Mn}$ ), that may result in an increase of toxic metals in the crop soil.

\section{Correlations between agricultural methods and metal concentration in coffee}

Table 5 reports the correlation matrix between the contents of $\mathrm{Ca}, \mathrm{Mg}, \mathrm{Fe}, \mathrm{Mn}, \mathrm{Zn}, \mathrm{Cu}, \mathrm{Cr}, \mathrm{Cd}, \mathrm{Pb}$ and $\mathrm{Ni}$ in green coffee (edible part) and three group of fertilizers (organic residues, SSP and NPK). All variables show a significant correlation with at least one other variable. No strong correlations between the organic residues and traditional or technological coffees are evident in the crop of 2006. However, high correlations are observed between organic coffees and organic residues used as fertilizer ( $r=0.912$ for organic coffee) and

Table 3. Mean total metal concentrations $\left(\mathrm{mg} \mathrm{kg}^{-1}\right), \mathrm{pH}$ and $\mathrm{OM}(\%)$ of the crop and natural soils

\begin{tabular}{lccccc}
\hline & Organic & Organic shaded & Traditional & Technological & Natural soils \\
\hline $\mathrm{pH}$ & $4.14 \pm 0.10 \mathrm{a}$ & $4.98 \pm 0.20 \mathrm{~b}$ & $4.87 \pm 0.10 \mathrm{abc}$ & $4.90 \pm 0.70 \mathrm{abc}$ & $4.65 \pm 0.10 \mathrm{c}$ \\
$\mathrm{OM}$ & $6.23 \pm 0.30 \mathrm{a}$ & $5.42 \pm 0.50 \mathrm{~b}$ & $5.47 \pm 0.70 \mathrm{ab}$ & $3.44 \pm 0.40 \mathrm{c}$ & $3.14 \pm 0.10 \mathrm{c}$ \\
$\mathrm{Cr}$ & $81 \pm 9 \mathrm{a}$ & $70 \pm 4 \mathrm{a}$ & $111 \pm 10 \mathrm{~b}$ & $122 \pm 4 \mathrm{~b}$ & $51 \pm 1 \mathrm{c}$ \\
$\mathrm{Ni}$ & $1.09 \pm 0.60 \mathrm{a}$ & $1.92 \pm 1 \mathrm{a}$ & $1.94 \pm 0.80 \mathrm{a}$ & $3.13 \pm 2 \mathrm{a}$ & $0.54 \pm 0.10 \mathrm{~b}$ \\
$\mathrm{Cu}$ & $10.9 \pm 0.5 \mathrm{a}$ & $10.8 \pm 1 \mathrm{a}$ & $15.8 \pm 0.8 \mathrm{c}$ & $23.2 \pm 1 \mathrm{~d}$ & $7.10 \pm 0.30 \mathrm{~b}$ \\
$\mathrm{Cd}$ & $3.62 \pm 0.30 \mathrm{a}$ & $3.98 \pm 1 \mathrm{a}$ & $3.20 \pm 0.50 \mathrm{a}$ & $3.50 \pm 0.50 \mathrm{a}$ & $0.27 \pm 0.10 \mathrm{~b}$ \\
$\mathrm{~Pb}$ & $14 \pm 1 \mathrm{a}$ & $12.6 \pm 0.4 \mathrm{a}$ & $93.0 \pm 0.2 \mathrm{c}$ & $122 \pm 2 \mathrm{~d}$ & $33.0 \pm 1 \mathrm{~b}$ \\
$\mathrm{Mn}$ & $69 \pm 13 \mathrm{a}$ & $66 \pm 19 \mathrm{a}$ & $75 \pm 9 \mathrm{a}$ & $161 \pm 21 \mathrm{~b}$ & $221 \pm 12 \mathrm{c}$ \\
$\mathrm{Zn}$ & $40 \pm 7 \mathrm{a}$ & $46 \pm 5 \mathrm{~b}$ & $64 \pm 12 \mathrm{c}$ & $70 \pm 16 \mathrm{bc}$ & $53 \pm 6 \mathrm{c}$ \\
\hline
\end{tabular}

Mean values with the same letters for the same variable between two cropping systems are not significantly different at the 5\% level (using a paired t-test analysis). 
Table 4. Metal concentration $\left(\mu \mathrm{g} \mathrm{g}^{-1}\right)$ in five organic residues used as fertilizer and three groups of commercial fertilizers

\begin{tabular}{lccccccc}
\hline & $\mathrm{Cd}$ & $\mathrm{Pb}$ & $\mathrm{Cr}$ & $\mathrm{Ni}$ & $\mathrm{Cu}$ & $\mathrm{Zn}$ & $\mathrm{Mn}$ \\
\hline Residue 1 & $<0.005$ & $<0.01$ & $<0.08$ & $7.2 \pm 1.7$ & $75 \pm 1$ & $253 \pm 3$ & $11.4 \pm 0.3$ \\
Residue 2 & $<0.005$ & $<0.01$ & $<0.08$ & $5.4 \pm 0.7$ & $61 \pm 2$ & $181 \pm 2$ & $23.9 \pm 0.3$ \\
Residue 3 & $<0.005$ & $<0.01$ & $<0.08$ & $7.5 \pm 2$ & $72 \pm 2$ & $121 \pm 1$ & $29.5 \pm 0.2$ \\
Residue 4 & $<0.005$ & $<0.01$ & $<0.08$ & $6.6 \pm 0.4$ & $108 \pm 0.7$ & $69 \pm 4$ & $36.5 \pm 0.6$ \\
Residue 5 & $<0.005$ & $<0.01$ & $<0.08$ & $7.2 \pm 0.5$ & $102 \pm 2$ & $448 \pm 3$ & $40.4 \pm 0.4$ \\
Fertilizer 1 & $17.7 \pm 1.7$ & $398 \pm 0.4$ & $95 \pm 1$ & $36.2 \pm 1.2$ & $36.8 \pm 0.8$ & $448 \pm 0.8$ & $85.7 \pm 0.6$ \\
Fertilizer 2 & $14.2 \pm 1.2$ & $356 \pm 0.6$ & $64.5 \pm 0.7$ & $41.8 \pm 0.6$ & $34.3 \pm 0.8$ & $438 \pm 0.9$ & $104 \pm 1.2$ \\
Fertilizer 3 & $16.9 \pm 0.6$ & $391 \pm 1.4$ & $72 \pm 1$ & $40.0 \pm 0.8$ & $34.4 \pm 1.8$ & $420 \pm 0.6$ & $131 \pm 0.5$ \\
\hline
\end{tabular}

Fertilizer 1: SSP triturated with particle sizes of less than $50 \mu \mathrm{m}$; Fertilizer 2: NPK 4-14-18; Fertilizer 3: SSP granulated with particle sizes of 2 mm.

( $r=0.906$ for organic shaded coffee). This fact leads to the following preliminary considerations: the strong correlations between metal concentrations in organic residues and the amounts in coffee fruit reflect the use of these residues as fertilizer. The correlations relatively weak observed for the pairs: organic residues-traditional coffee $(r=0.352)$ and organic residues-technological coffee $(r=0.361)$, indicate that organic residues were not used as fertilizer in the traditional and technological farms in the crop of 2006.

In the crop of 2007, strongest correlations, significant at $\mathrm{p}<0.05$, are observed for pairs: organic residues- traditional coffee $(r=0.743)$ and organic residues-technological coffee $(r=0.700)$, suggesting that the residue from the coffee processing was used as fertilizer in those two coffee farms (traditional and technological).

\section{Multivariate analysis}

\section{Principal component analysis}

Principal components analysis (PCA) was performed on data sets concerning coffee tissues samples (leaf and fruit) and soil samples extracted by the two procedures (Mehlich1 and EPA3050) collected in the four farms (organic, organic shaded, traditional and technological). PCA was applied to the autoscaled data matrix in order to provide a data structure study in a reduced dimension while retaining the maximum amount of variability present in data. A Varimax rotation with Kaiser normalization of main components was preferred to identify elements responsible for the grouping of the objects (coffee, leaf and soil). Two components were extracted describing approximately $76 \%$ of the common variance

Table 5. Correlation matrix between the variables of fertilizers (organic residues, SSP and NPK) and organic, organic shaded, traditional and technological coffees

\begin{tabular}{|c|c|c|c|c|c|c|c|}
\hline & & Coffee 1 & Coffee 2 & Coffee 3 & Coffee 4 & Residue & Fertilizer NPK \\
\hline \multirow[t]{7}{*}{ Crop 2006} & Coffee 1 & 1.000 & & & & & \\
\hline & Coffee 2 & $0.998^{\mathrm{b}}$ & 1.000 & & & & \\
\hline & Coffee 3 & -0.033 & -0.050 & 1.000 & & & \\
\hline & Coffee 4 & -0.024 & -0.040 & $1.000^{\mathrm{b}}$ & 1.000 & & \\
\hline & Residue & $0.912^{\mathrm{b}}$ & $0.906^{\mathrm{b}}$ & 0.352 & 0.361 & 1.000 & \\
\hline & Fertilizer NPK & $0.984^{\mathrm{b}}$ & $0.983^{\mathrm{b}}$ & 0.018 & 0.027 & $0.934^{\mathrm{b}}$ & 1.000 \\
\hline & Fertilizer SSP & $0.985^{\mathrm{b}}$ & $0.985^{\mathrm{b}}$ & 0.022 & 0.031 & $0.933^{\mathrm{b}}$ & $1.000^{\mathrm{b}}$ \\
\hline \multirow[t]{7}{*}{ Crop 2007} & Coffee 1 & 1.000 & & & & & \\
\hline & Coffee 2 & $0.991^{\mathrm{b}}$ & 1.000 & & & & \\
\hline & Coffee 3 & $0.983^{\mathrm{b}}$ & $0.979^{\mathrm{b}}$ & 1.000 & & & \\
\hline & Coffee 4 & $0.992^{\mathrm{b}}$ & $0.989^{\mathrm{b}}$ & $0.998^{\mathrm{b}}$ & 1.000 & & \\
\hline & Residue & $0.649^{\mathrm{a}}$ & 0.590 & $0.743^{\mathrm{a}}$ & $0.700^{\mathrm{a}}$ & 1.000 & \\
\hline & Fertilizer NPK & 0.176 & 0.096 & 0.298 & 0.238 & $0.858^{\mathrm{b}}$ & 1.000 \\
\hline & Fertilizer SSP & 0.179 & 0.099 & 0.301 & 0.241 & $0.858^{\mathrm{b}}$ & $0.913^{\mathrm{b}}$ \\
\hline
\end{tabular}

Organic coffee (coffee 1); Organic shaded coffee (coffee 2); Traditional coffee (Coffee 3); Technological coffee (coffee 4). Correlation coefficients are significant at $\mathrm{p}<0.05\left(^{(\mathrm{a})}\right.$ or $\mathrm{p}<0.01\left(^{\mathrm{b}}\right)$. 
The scores and loadings of the first two PCs (PC1 and PC2) are plotted in Figure 1. The PCs scores plot (PC1 and PC2) (Figure 1a) shows the spatial distribution of the samples. It is possible to distinguish four different clusters. The loading plot (Figure 2b) shows the relationship between variables and how much they influence the system.

The group circled in Figure 1a, located on the positive side of the PC1 contains coffee and some leaf samples. As it can be seen, organic coffee samples produced in 2007 are characterized by higher values of component PC1, in contrast to the organic coffee produced in 2006 and technological coffee samples produced in 2007 described by lower values of PC1. This fact leads to the following preliminary considerations: the strong similarity between technological coffee samples of 2007 and organic coffee samples of 2006 may have happened, because the samples of coffee organic were collected during the first year after the start of organic management. However, no similarity between the organic coffee of 2007 and any other coffee sample is evident in Figure 1a. This can be explained, because the organic coffee (crop of 2007) was produced in the second year after the start of organic management. Furthermore, the differentiation of organic coffee (crop of 2007) supports the premise of the effectiveness of conversion period to guarantee a product characteristic of organic farming. The period of time between the start of organic management and cultivation of crops iadopted $s$ known as the conversion period. As already mentioned, the minimum conversion period in Brazil for perennial plants (including coffee cultivation) is 24 months from the date of starting organic management. Depending upon the past use of the land and ecological situations, the certification agency can extend or reduce the minimum conversion period.

On the other hand, in the cluster formed by coffee samples can be distinguished three subclusters. From the left, the first subcluster is composed of organic and technological coffees (crops of 2006 and 2007, respectively) and three leaf samples. From the left, the first subcluster is composed of organic and technological coffees (crops of 2006 and 2007, respectively) and three leaf samples. The loadings plot (Figure 1b) indicates that this grouping is influenced mainly by the levels of $\mathrm{Pb}$. The second subcluster composed of organic shaded and traditional coffees (crops of 2006 and 2007), technological coffee (crop of 2006) and four leaf samples is influenced mainly by the levels of $\mathrm{Mg}, \mathrm{Ni}$ and Ca. Finally, the third subcluster only formed by organic coffee (crop of 2007) is influenced mainly by the levels of $\mathrm{Fe}, \mathrm{Zn}$ and $\mathrm{Cu}$. Thus, the first principal component might be interpreted as an indicator of coffee quality
Other important information is revealed in the cluster circled in Figure 1a, located on the positive side of the PC2. As it can be seen, a clear separation between soils of traditional and technological farms (digested by the USEPA 3050 procedure) with the others soil samples is obtained. The loadings plot (Figure 1b) indicates that the grouping of soils samples circled in Figure 1a is influenced mainly by the levels of $\mathrm{Cd}, \mathrm{Cr}$ and $\mathrm{Mn}$. This differentiation can be attributed to the export of $\mathrm{Cd}, \mathrm{Cr}$ and $\mathrm{Mn}$ for the crop plants in the organic cultivations.
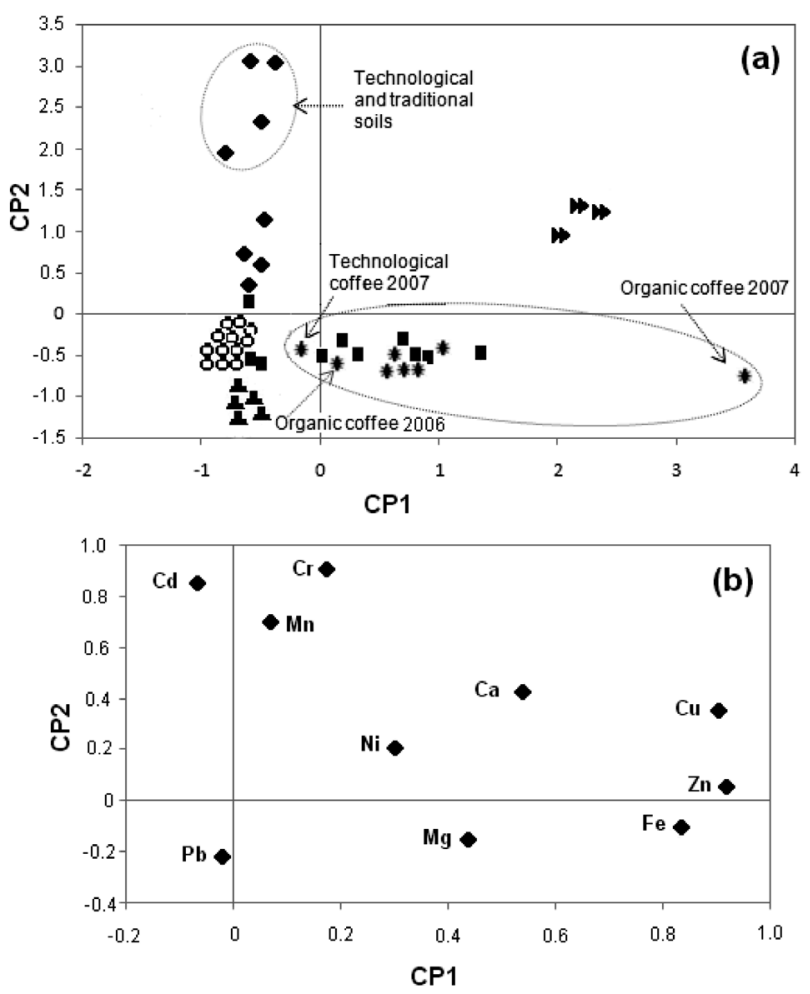

Figure 1. Plots of PCA (a) scores for coffee, leaf and soil samples (b) loadings: Coffee (*); Leaf (匹); Soil EPA extraction $(\bullet)$; Soil Mehlich extraction (O); Fertilizers (\$); Organic residue (n).

\section{Cluster analysis}

Cluster analysis comprises of a series of multivariate methods which are used to find true groups of data. In clustering, the objects are grouped such that similar objects fall into the same class. The hierarchical method of cluster analysis (Ward's clustering procedure), which is used in this study, has the advantage of not requiring any prior knowledge of the number of clusters, while the nonhierarchical method does require such knowledge.

The dendogram obtained by evaluation of the concentrations of $\mathrm{Ca}, \mathrm{Mg}, \mathrm{Fe}, \mathrm{Mn}, \mathrm{Zn}, \mathrm{Cu}, \mathrm{Cr}, \mathrm{Cd}, \mathrm{Pb}$ and $\mathrm{Ni}$ in samples of coffee tissues (leaf and fruit) and soil extracted by the two procedures (Mehlich1 and EPA3050) collected in the two transitional organic farms (organic and 
organic shaded) are shown in Figure 2. It is possible to distinguish three different clusters. The first cluster contains leaf and fruit, tissue collected in August and soil (fraction extracted by Mehlich1 procedure) collected in April. This fact leads to the following preliminary considerations: the strong correlations between metal concentrations in available fraction in soil and the amounts in coffee fruit reflects the importance of the Mehlich extractant for providing a suitable chemical evaluation of the amount of metals available for plant uptake. This could be caused by the addition of organic matter before the flowering tree period. When high levels of organic matter are added to soils, a greater uptake of metals and nutrients by plants occurs because the soluble organic matter acts as a "cation carrier" facilitating metal diffusion from soil particles to roots. ${ }^{17,29-33}$

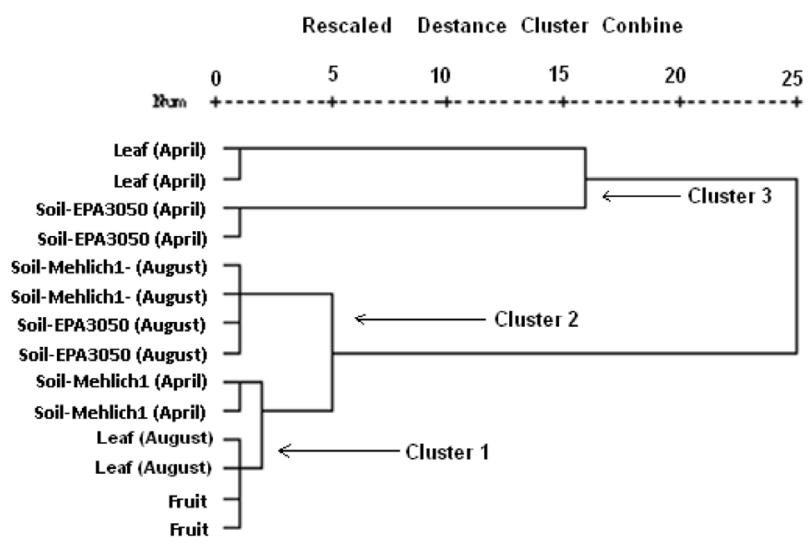

Figure 2. Dendogram of cluster analysis (Ward's method) of organic and organic shaded farms.

\section{Conclusions}

The results obtained from this study suggest that $\mathrm{Cd}, \mathrm{Cu}$, $\mathrm{Zn}$ and other toxic elements contained in some inorganic fertilizers used in the traditional and technological coffee farms, and relatively high contents of $\mathrm{Cu}, \mathrm{Zn}$, and other metals in organic manures used in organic coffee farms, may cause an increase of toxic metals in the crop soil, be taken up by plants, and passed on in the food chain.

The application of statistical methods (cluster and principal components analysis) revealed that the coffees cultivated during the first year after the start of organic management presented high similarity with the coffees cultivated by technological and traditional managements. However, some coffees cultivated during the second year after the start of organic management presented low similarity with the coffees cultivated by other managements. This fact revealed the importance of the conversion period to guarantee a product genuinely resulting from organic farming.

\section{Acknowledgments}

The authors thank Fundação de Amparo à Pesquisa do Estado da Bahia (FAPESB) and Coordenação de Aperfeiçoamento de Pessoal de Nível Superior (CAPES) for financial support.

\section{References}

1. Li, J. T.; Qiu, J. W.; Wang, X. W.; Zhong, Y.; Lan, C. Y.; Shu, W. S.; Environ. Pollut. 2006, 143, 159.

2. Rieuwerts, J. S.; Ashmore, M. R.; Farago, M. E.; Thornton, I.; Sci. Total Environ. 2006, 366, 864.

3. Cuadra, M.; Rydberg, T.; Ecol. Model. 2006, 196, 421.

4. Pinto, L. S.; Lopez, V. V.; Ferrer, G. J.; Marcial, N. R.; Montoya, G.; Sinclair, F. L.; Biodivers. Conserv. 2007, 16, 419.

5. Hernández, A. J.; Alexis, S.; Pastor, J.; Sci. Total Environ. 2007, 378,36 .

6. Sinha, S.; Gupta, A. K.; Bhatt, K.; Pandey, K.; Rai, U. N.; Singh, K. P.; Environ. Monit. Assess. 2006, 115, 1.

7. Paulose, B.; Datta, S. P.; Rattan, R. K.; Chhonkar, P. K.; Environ. Pollut. 2007, 146, 19.

8. Tsadilas, C. D.; Karaivazoglou, N. A.; Tsotsolis, N. C.; Stamatiadis, S.; Samaras, V.; Environ. Pollut. 2005, 134, 239.

9. Dungan, R. S.; Dees, N. H.; Water, Air, Soil Pollut. 2007, 183, 213.

10. Evangelou, M. W. H.; Klöss, S. K., Ebel, M.; Schaeffer, A.; Water, Air, Soil Pollut. 2007, 182, 407.

11. Muthanna, T. M.; Viklander, M.; Gjesdahl, N.; Thorolfsson, S. T.; Water, Air, Soil Pollut. 2007, 183, 391.

12. Overesch, M.; Rinklebe, J.; Broll, G.; Neue, H. U.; Environ. Pollut. 2007, 145, 800.

13. Bray, D. B.; Sanchez, J. L. P.; Murphy, E. C.; Society and Natural Resources 2002, 15, 429.

14. Siu, Y.; Mejia, G.; Saavedra, J. M.; Bull. Environ. Contam. Toxicol. 2007, 78, 400.

15. Figueiredo, F. E. R.; Assis, R. L.; B. Reydon, P.; J. Food Agric. Environ. 2003, 1, 239.

16. Lorena, S. P.; Víctor, V. L.; Guillermo, J. F.; Neptalí, R. M.; Guillermo, M.; Fergus, L. S.; Biodivers. Conserv. 2007, 16, 419.

17. Dos Santos, J. S.; Dos Santos, M. L. P.; Conti, M. M.; Dos Santos, S. N.; Oliveira, E.; Food Chem. 2009, 115, 1405.

18. Santos, E. E.; Lauria, D. C.; da Silveira, C. L. P.; Sci. Total Environ. 2004, 327, 69.

19. Neunhäuserer, C.; Berreck, M.; Insam, H.; Water, Air, Soil Pollut. 2001, 128, 85.

20. Maenpaa, K. A.; Kukkonen, J. V. K.; Lydy, M. J.; Arch. Environ. Contam. Toxicol. 2002, 43, 389.

21. Aucejo, R. M.; Chover, T. A.; Sáez, R. M.; Estellés, M. L.; Anal. Chim. Acta 2007, 581, 78. 
22. Siripatrawan, U.; Harte, B. R.; Anal. Chim. Acta 2007, 581, 63.

23. Environmental Protection Agency (EPA); Methods for Chemical Analysis of Water and Wastes, (EPA 600/4-79-020), Cincinnati, 1983.

24. Nguyen, H. L.; Leermakers, M. L.; Elskens, M.; De Ridder, F.; Doan, T. H., Baeyens, W.; Sci. Total Environ. 2005, 341, 211.

25. Sena, M. M.; Poppi, R. J.; Frighetto, R. T. S.; Valarini, P. J.; Quim. Nova 2000, 23, 547.

26. Lee, P. W.; Handbook of Residue Analytical Methods for Agrochemicals, John Wiley \& Sons Ltd.: New York, 2003.

27. Page, A. L.; Methods of Soil Analysis Part 2, American Society of Agronomy: Madison, Wisconsin, 1982.

28. International Organisation for Standardisation (ISO); Soil Quality Determination of pH, ISO No. 10390, ISO: Geneva, 1994.
29. Felipe-Sotelo, M; Cal-Prieto, M. J.; Ferré, J.; Boqué, R.; Andrade, J. M.; Carlosena, A.; J. Anal. At. Spectrom. 2006, 21, 61.

30. Huang, B.; Kuo, S.; Bembenek, R.; Water, Air, Soil Pollut. 2003, 147, 109.

31. Houba, V. J. G.; Lexmond, T. M.; Novozamsky, I.; Van der Lee, J. J.; Sci. Total Environ. 1996, 178, 21.

32. Yang, Q.; Li, H.; Long, F.; Environ. Monit. Assess. 2007, 130, 271.

33. Micó, C.; Recatala, L.; Peris, M.; Sanchez, J.; Chemosphere 2006, 65, 863 .

Received: November 13, 2009

Web Release Date: April 8, 2010 